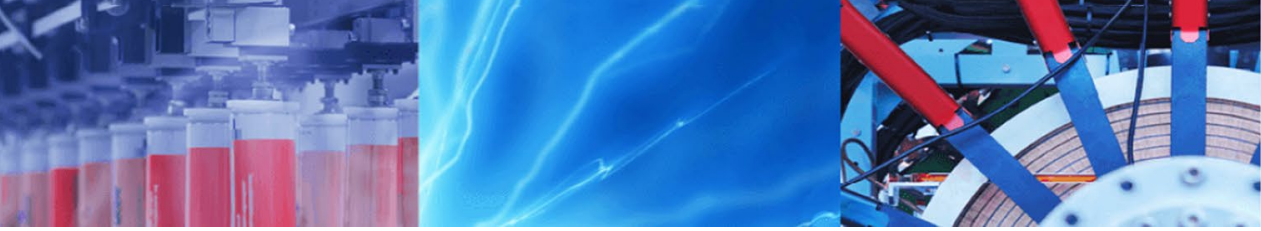

Research Article

\title{
Physical characterization and alkali carbonate reactivity (ACR) potential of the rocks from Bauhti Pind and Bajar area Hassan Abdal, Pakistan
}

\author{
Mustansar Naeem ${ }^{1} \cdot{\text { Tehseen } \mathrm{Zafar}^{2} \cdot \text { M. Touseef Bilal }}^{1} \cdot$ Abiola Oyebamiji $^{2}$
}

C Springer Nature Switzerland AG 2019

\begin{abstract}
This study is conducted to evaluate aggregate characteristics and alkali carbonate reactivity (ACR) potential of carbonate rocks of the Bouhti Pind and Bajar area, Hassan Abdal, Pakistan. Physical and chemical tests were performed to assess aggregate suitability. Mean specific gravity (2.65-2.65), water absorption (0.51-0.68\%), Los Angeles abrasion (24.78-26.10\%) and sulphate soundness values (2.86-4.25\%) of the carbonate rocks of these areas are within specified limits of their respective standards. Petrographic studies of Bajar area reveal the presence of $96.3 \%$ calcite, $2 \%$ clays, $1 \%$ hematite and $0.7 \%$ quartz. These rocks do not contain dolomite and show no expansion in rock cylinder test. Therefore, the aggregate is not prone to ACR and can be used in cement concrete. Rocks of Bouhti Pind area have mean $92 \%$ calcite, $3.8 \%$ dolomite, $2 \%$ clays, $1.2 \%$ hematite and $1 \%$ monocrystalline quartz. The amount of deleterious minerals specifically dolomite and clays are below the maximum allowed limit to initiate ACR. However, one of the rock cylinders shows $0.043 \%$ expansion which is below threshold limit of $0.10 \%$ to cause ACR as specified in ASTM C-585. Hence, these carbonate rocks qualify physical characterization and ACR tests and can be used in the construction of roads and in cement concrete.
\end{abstract}

Keywords Physical characterization · Alkali carbonate reactivity $\cdot$ Petrographic studies · Pakistan

\section{Introduction}

Aggregates are naturally occurring materials that should be inert and durable which can form firm bond when used as a source of construction material in cement concrete $[25,47]$. Rock-crushed aggregate is produced for utilization in cement and asphalt concrete, in roads, railways as well as riprap material $[1,10,18,27,43]$. Aggregate is an important constituent in cement and asphalt concrete. Cement concrete contains about $70 \%$ aggregate, and strength of concrete depends upon the durability of the aggregate [42]. The construction industry primarily required a huge amount of aggregates $[17,44]$. In developing countries, aggregate plays a vital role in the construction industry. But in Pakistan, this is one of the most neglected sectors where only limited aggregate sources have been explored $[23,50]$. The construction industry of Pakistan uses mostly carbonate aggregate which is abundantly available in various parts of the country [35, 38, 45, 51]. Margala Hill Limestone, Kirana Hills of Sargodha and gravels of Attock area are common source of aggregate used in engineering projects $[2,9,31]$. Meanwhile, limestone of Salt Range, Kohat and Hazara areas is also considered as significant aggregate source $[15,16,42,50]$. On the other hand, Malkani and Mahmood $[28,29]$ reported vast and huge deposits of easily mineable limestone deposits from Sulaiman, Kirthar and Balochistan basins.

An aggregate should possess desirable mechanical, chemical and mineralogical properties for use as aggregate source [30]. Different tests like water absorption,

$\square$ Tehseen Zafar, tehseenabbas11@yahoo.com; Mustansar Naeem, naeem29pk@yahoo.com; Abiola Oyebamiji, abiolaoye@mail.gyig.ac.cn | Institute of Geology, University of the Punjab, Lahore, Pakistan. ${ }^{2}$ Institute of Geochemistry, Chinese Academy of Sciences, Guiyang 550081, China.

SN Applied Sciences (2019) 1:696 | https://doi.org/10.1007/s42452-019-0736-5

Received: 17 March 2019 / Accepted: 4 June 2019 / Published online: 10 June 2019

SN Applied Sciences 
specific gravity, Los Angeles abrasion values and sodium sulphate soundness are carried out to determine the suitability of the material, whereas modal mineralogical composition of the aggregate is determined to assess the presence of deleterious materials such as dolomite, clays and strained quartz found in carbonate aggregate. These minerals constituents control physical and chemical characteristics of an aggregate and can interact with alkali hydroxides in the cement to cause deleterious expansion as well as deterioration in structure and swelling in the concrete fabric, ultimately failure of the structure $[33,46]$.

Alkali-carbonate reaction $(A C R)$ occurs when dolomite of carbonate aggregate reacts with alkalis hydroxides of the cement in the presence of moisture. The dolomite becomes dedolomitized as brucite mineral and exerts tensile stress which produces cracks. This allows the entry of water in the presence of clay minerals resulting in failure of structure $[13,19,21,46]$. The occurrence of dolomite and clays can be found out by petrographic technique, while expansion behaviour can be determined through Rock Cylinder method (ASTM C-586).

Carbonate rocks of the Potwar, Kohat, Salt Range, Hazara and Kala Chitta Range were investigated by many researchers (e.g. [16, 20, 22, 42]). But little attention was given to the aggregate characteristics of the carbonate rocks of these areas. Engineering properties of aggregate of the Margala Hill Limestone and Lockhart Limestone of Rumli and Hazara area were presented by Naeem et al. [31] and Sadiq et al. [37]. Chaudhry et al. [10], Ahsan et al. [1] and Zaidi et al. [50] discussed the physical characterization of aggregates of Salt Range and Kirana Hills, Sargodha area. However, physical and chemical characteristics of the carbonate rocks of Bouhti Pind and Bajar area have not been documented in the literature. Moreover, ACR potential of these dolomitic carbonate rocks has not been presented prior to this contribution. Hence, there was a dire need to investigate the physical and chemical properties and ACR potential of the carbonate rocks of Bouhti Pind and Bajar area to assess their suitability as aggregate sources for use as construction material for engineering projects.

\section{Tectonics}

The Bouhti Pind and Bajar area lie in Cambellpur Basin, Lesser Himalaya, NW Pakistan [48]. The Lesser Himalaya is delimited by Main Boundary Thrust (MBT) in the south and Main Central Thrust (MCT) in the north [36, 39]. The Bouhti Pind and Bajar areas are located near Hassan Abdal in the north-east of Kala Chitta Range and in the east of Attock Cherat Ranges [8]. The area falls in active folding and thrusting zone in the foreland of Himalayan mountain belt in Pakistan (Fig. 1). Hassan Abdal lies in NE of Kherimar Hills and south of Gandhar Range. Gandhar Range and Kherimar Hills are situated in the north of Main Boundary Thrust. Kherimar Hills are truncated by Nathiagali Thrust which changes into Hassartang Fault in the west $[14,26]$. Gandhar Range is located in the north-east of Kala Chita Range and in the north of Hassan Abdal/Kherimar Hills (Fig. 1). The Kala Chitta Range is an elongated EW trough situated along the northwestern margin of the Indo-Pak Plate [32]. The AttockCherat Range is situated in the north of the Kala Chitta Range [14]. Panjal Thrust truncates in Cambellpur Basin north-east of Gandhar Range which extends to Khairabad Thrust in the west. Kala Chitta Range is bounded by MBT in the southern side, which further converts into Murree Thrust in the east and Hassartang Fault in the west [49].

\section{Stratigraphy}

Hazara Formation, Samana Suk Formation, Lockhart Limestone and Patala Formation are exposed in Bouhti Pind and Bajar area, Hassan Abdal. The Hazara Formation is the oldest (Precambrian) rock unit. The Samana Suk Formation of Jurassic age unconformably overlies the Hazara Formation which is overlain by Lockhart Limestone of Palaeocene age. However, due to erosion, the Patala Formation is not exposed in this area [20]. The Hazara Formation predominantly comprised of slate and phyllite. In Bouhti Pind and Bajar area, grey to dark-grey, medium to thick-bedded limestone of Samana Suk Formation is exposed. The limestone presents yellowish-brown weathering colour. At a few places, the limestone is massive shows jet-black colour. However, the limestone presents brittle behaviour. Yellowish dolomitic patches are present in the limestone of Bouhti Pind area. The limestone contains white calcite veins, fractures and joints. The limestone shows nodular behaviour in the study areas. Solution weathering is commonly found in the carbonate rocks of the Bouhti Pind area. The Lockhart Limestone consists of light-grey to grey, medium to thick-bedded, massive limestone [40]. In Trans-Indus Range, the Lockhart Limestone is greyish, medium-bedded with minor marl and calcareous shale. In the Hazara and Kala Chitta area, the dark-grey limestone is found with shale and intercalations [40]. The limestone is of bituminous nature that gives odour on fresh surface. This limestone is well developed in the Kohat-Potwar area $[20,22]$. The Hassan Abdal hills are composed of Jurassic-Palaeocene rock units mainly Lockhart Limestone which lies on Samana Suk Formation. The Wah Hill mainly consists of Lockhart Limestone [11]. 


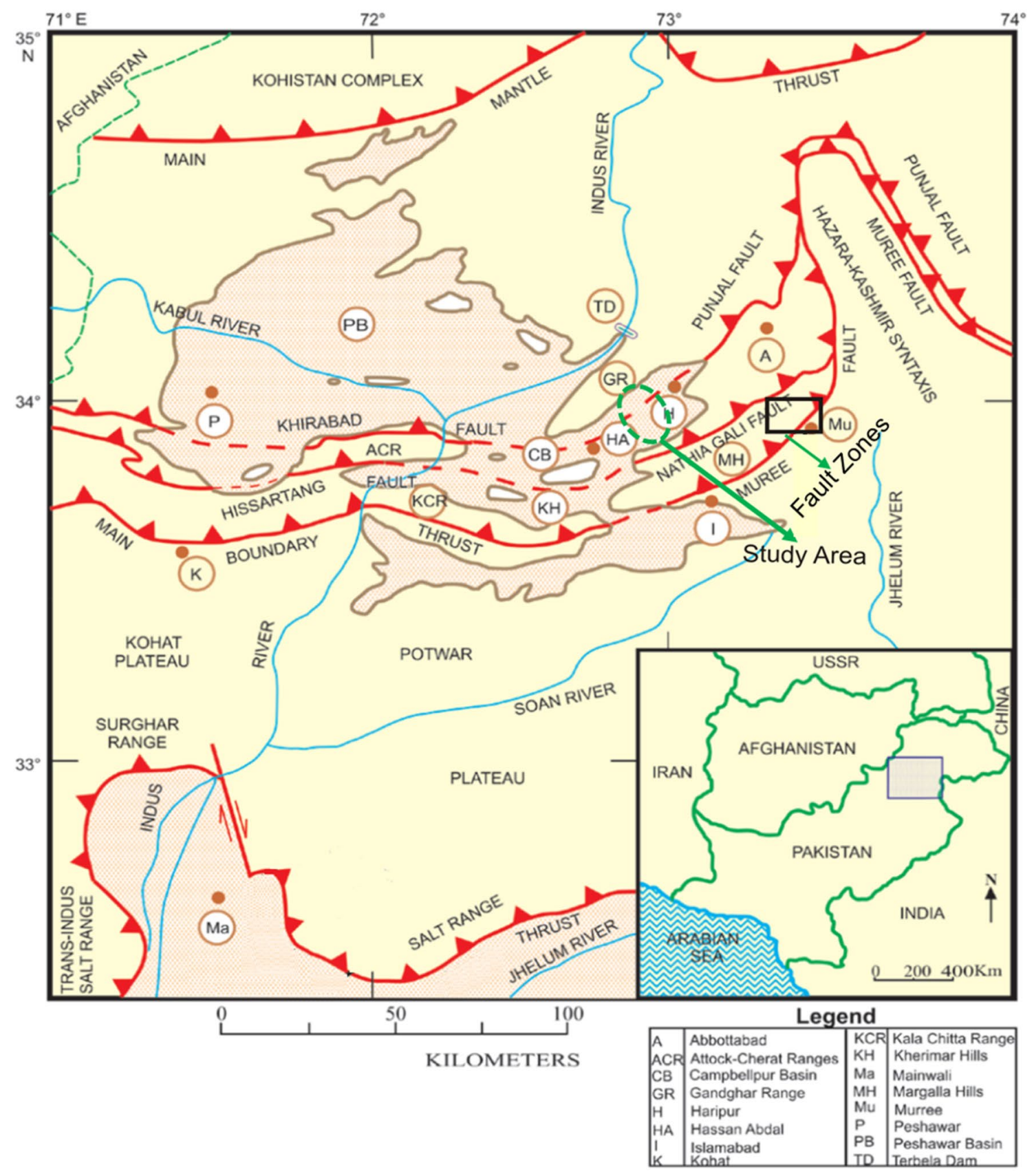

Fig. 1 Reveals tectonic map and location of the study area

\section{Methodology}

Representative carbonate rock samples of Bouhti Pind and Bajar area were washed and dried in an oven at $110^{\circ} \mathrm{C}$ for $24 \mathrm{~h}$. Physical and chemical tests were performed according to the specifications of their respective standards. Specific gravity, water absorption, Sulphate soundness and Los Angeles abrasion value were determined by using ASTM standards (C-127, C-88 and C-131-69). The results are presented in Table 1.

\subsection{Petrography [6]}

The carbonate rock samples of Bouhti Pind and Bajar area were washed and cut into thick slabs by using diamond cutter. These slabs were washed and grinded to make smooth surfaces and mounted on glass slide of $1 \mathrm{~mm}$ thick with $26 \times 46 \mathrm{~mm}$ dimension, with the help of Lackside-70 epoxy resin that has 1.54 index of refraction. These mounted slabs were grinded with 600- and 800-mesh SiC powders to reduce their thickness. Final grinding and 
Table 1 Specific gravity, water absorption, sulphate soundness and Los Angles abrasion values of the carbonate rocks of Bouhti Pind (BP) and Bajar (BJ) area

\begin{tabular}{llllll}
\hline S. no. & Sample no. & Specific gravity & $\begin{array}{l}\text { Water absorp- } \\
\text { tion } \%\end{array}$ & $\begin{array}{l}\text { Sulphate } \\
\text { soundness } \%\end{array}$ & $\begin{array}{l}\text { Los Angles } \\
\text { abrasion } \\
\text { value } \%\end{array}$ \\
\hline 1 & & & & - & - \\
2 & BP-1 & 2.67 & 0.60 & 2.45 & 23.40 \\
3 & BP-2 & 2.64 & 0.60 & 2.60 & 29.30 \\
4 & BP-3 & 2.66 & 0.40 & - & - \\
5 & BP-4 & 2.64 & 0.40 & 2.95 & 25.25 \\
6 & BP-5 & 2.63 & 0.60 & 2.80 & - \\
7 & BP-6 & 2.67 & 0.44 & - & 21.20 \\
8 & BP-7 & 2.65 & 1.00 & - & - \\
9 & BP-8 & 2.68 & 0.40 & 3.50 & - \\
Mean value & BP-9 & 2.69 & 0.20 & 2.86 & 24.78 \\
10 & & 2.65 & 0.51 & - & 23.80 \\
11 & BJ-10 & 2.68 & 0.60 & 3.18 & 26.10 \\
12 & BJ-11 & 2.66 & 0.60 & - & - \\
13 & BJ-12 & 2.65 & 0.40 & 4.63 & 28.40 \\
14 & BJ-13 & 2.72 & 0.60 & 4.95 & - \\
Mean value & BJ-14 & 2.58 & 1.20 & 4.25 & 26.10 \\
\hline
\end{tabular}

polishing were done with 1200-micron powder to $30 \mu \mathrm{m}$ thickness. These slides were stained with Alizarin Red-S and potassium ferricyanide to differentiate between ferron and non-ferron carbonate minerals. The thin section slides were studied under petrographic microscope employing different magnifications.

The carbonate rocks of the Bouhti Pind and Bajar area contain 92-96.3\% calcite as major mineral with subordinate amounts of $0-3.8 \%$ dolomite, $2-2.1 \%$ clays, $0.7-1.0 \%$ quartz and 1.0-1.2\% hematite (Fig. 2a-h). Dolomite occurs as rhombs with fine-grained calcite material (Fig. 2b). Calcite is also found as veins (Fig. 2c, h). Carbonates are present as microsparite or micrite (Fig. 2f). Some of the slides contain fossils and their broken shells (Fig. 2c). The carbonate rocks of the Bouhti Pind and Bajar are classified into packstone, wackstone and grainstone [12]. Modal mineralogical composition of the Bauhti Pind and Bajar carbonate rocks is given in Table 2.

\subsection{Alkali-carbonate reactivity (ASTM C-586)}

Using the specifications of ASTM C-586, 25 carbonate rock cylinders of Bauhti Pind and Bajar area having $35 \mathrm{~mm}$ length and $9 \mathrm{~mm}$ diameter were prepared. These cylinders were immersed in $1 \mathrm{~N} \mathrm{NaOH}$ solution for 28 days at room temperature. Length and diameter of these carbonate rock cylinders were measured before and after 28 days immersion in the $1 \mathrm{~N} \mathrm{NaOH}$ solution and recorded the change in these parameters. Results of the study are shown in Table 3.

\section{Discussion}

Physical and chemical characterization study was carried out to assess aggregate properties and ACR potential of carbonate rocks of the Bouhti Pind and Bajar areas. Different tests were performed to explore potential of these rocks for utilization as construction material for engineering projects. Mean specific gravity of the carbonate rocks of Bouhti Pind and Bajar area is 2.65. The specified limit of specific gravity is 2.7 for use in cement concrete and asphalt mixes [3]. This shows that mean specific gravity of carbonate rocks of both the areas lies within limits of the respective standard. Water absorption capacity of aggregates plays an important role in the strength of concrete [31]. Porous aggregates have higher water absorption values and lower strength [34]. In extreme climate, the absorbed water in aggregate is subjected to freeze-thaw process, producing cracks and damaging the concrete [41]. Mean water absorption values of carbonate rocks of the Bouhti Pind and Bajar area are $0.51 \%$ and $0.68 \%$, respectively. ASTM C-127 allows maximum water absorption values up to $2 \%$ which means that average water absorption values of carbonate rocks of both the areas fall within limits of the standard that renders suitability of these rocks for utilization as aggregate in cement concrete.

Los Angeles abrasion values (LAAV) determines the abrasion resistance of an aggregate when used as construction material in roads [24]. Average LAAV of the Bouhti Pind and Bajar carbonate rocks are $24.78 \%$ and $26.10 \%$, respectively. The upper limit of LAAV of aggregates for asphalt mixes, cement concrete and roads are 
Fig. 2 Microphotographs $\mathbf{a}-\mathbf{h}$ showing various features of carbonate rocks of Bouhti Pind and Bajar areas: a sample $\mathrm{BP}-1 \mathrm{~b}$ indicating fossils (Foss) presence, dolomite (Dol) rhombs and calcite (Cal). b Sample BP-2b portrays tiny dolomite (Dol) rhombs and rhombohedral cleavage in calcite (Cal). c Calcite vein and broken pieces of shells in Sample BP-4b. d, e Samples BP-5b, BJ-10a signifies fossils and calcite presence. $\mathbf{f}$ Sparite and fossils in BJ-14a. $\mathbf{g}, \mathbf{h}$ BJ-13c, 10b shows Lockhartia, bioclasts and calcite vein with cleavage
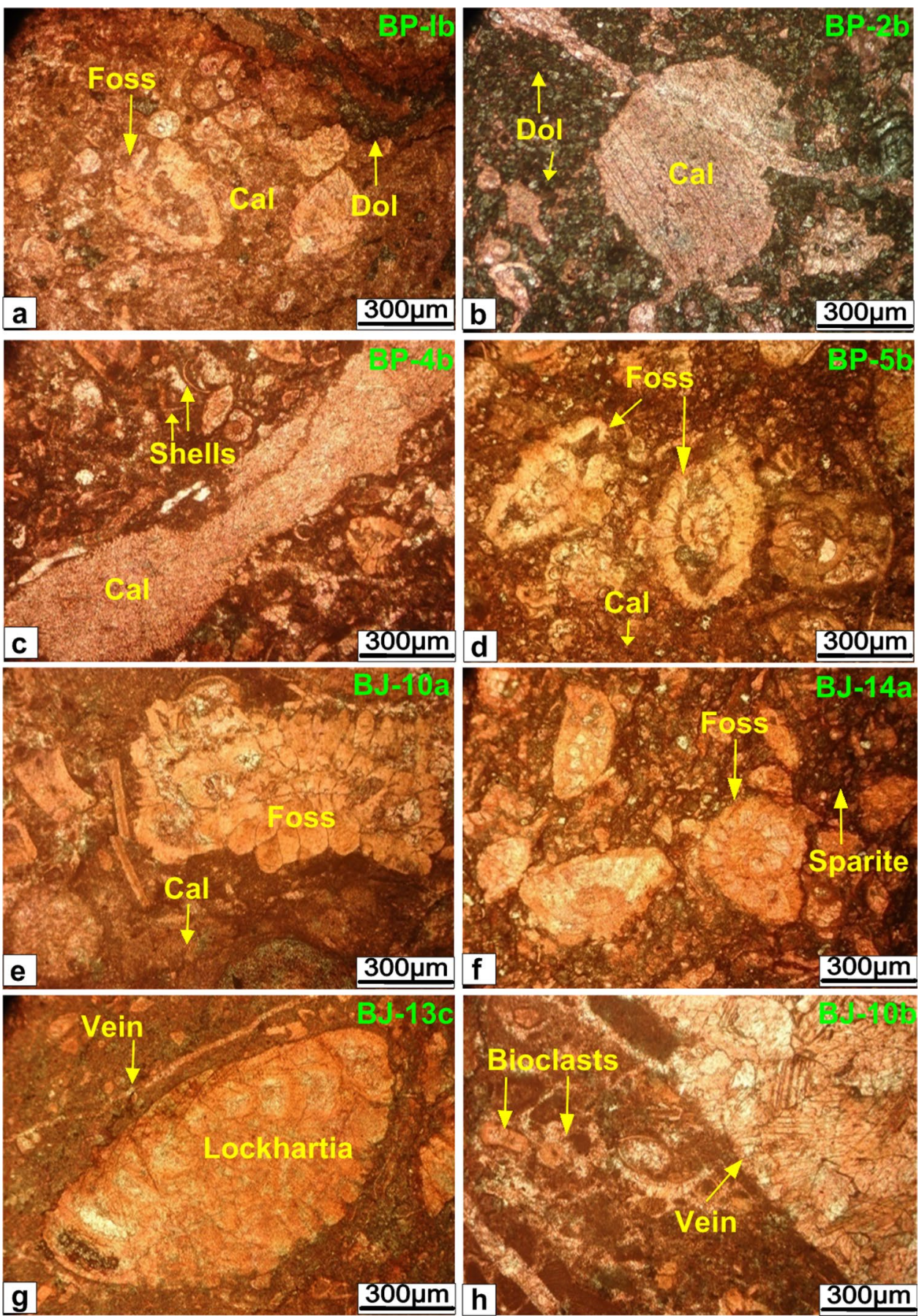

$30 \%, 40 \%$ and $50 \%$, respectively [4]. The LAAV of the carbonate rocks of both the areas are within limits of the respective standard for utilization in asphalt mixes, cement concrete and for the construction of roads.

Sulphate soundness value reflects weathering resistance of an aggregate [10]. The specified upper limits of sulphate soundness values of carbonate aggregate use in cement concrete and construction of roads are $10 \%$ and $12 \%$, respectively [7]. Higher than standard values suggest vulnerability of rock towards weathering. While lower values indicate soundness of rocks. Mean sulphate soundness values of the carbonate rocks of the Bouhti Pind and Bajar area are $2.86 \%$ and $4.25 \%$, respectively. These values are lower than standard limits suggesting the soundness of these rocks and suitable for utilization in cement concrete and construction of roads.

Modal mineralogical composition of rocks plays an important role in the identification of deleterious components that can react with the alkalis of cement when used as an aggregate source in cement concrete [33, 
Table 2 Modal mineralogical composition and Dunham classification of the rocks of Bauhti Pind and Bajar areas

\begin{tabular}{|c|c|c|c|c|c|c|c|}
\hline S. no. & Sample no. & Calcite \% & Dolomite \% & Quartz \% & Clays \% & Hematite \% & $\begin{array}{l}\text { *Dunham } \\
\text { classifica- } \\
\text { tion }\end{array}$ \\
\hline 1 & BP-1a & 85 & 10 & 2 & 2 & 1 & Packstone \\
\hline 2 & $B P-1 b$ & 90 & 6 & - & 2 & 2 & Packstone \\
\hline 3 & BP-2a & 90 & 6 & 1 & 1 & 2 & Packstone \\
\hline 4 & BP-2b & 75 & 20 & 1 & 2 & 2 & Packstone \\
\hline 5 & BP-3a & 90 & 6 & - & 3 & 1 & Packstone \\
\hline 6 & BP-3b & 82 & 14 & 1 & 3 & - & Packstone \\
\hline 7 & BP-4a & 95 & - & 1 & 2 & 2 & Packstone \\
\hline 8 & BP-4b & 97 & - & - & 1 & 2 & Packstone \\
\hline 9 & BP-5a & 94 & - & 2 & 3 & 1 & Wackstone \\
\hline 10 & BP-5b & 94 & 2 & 1 & 2 & 1 & Packstone \\
\hline 11 & BP-5C & 94 & - & 2 & 3 & 1 & Packstone \\
\hline 12 & ВР-6а & 95 & - & - & 3 & 2 & Wackstone \\
\hline 13 & BP-6b & 95 & - & - & 3 & 2 & Wackstone \\
\hline 14 & BР-6C & 97 & - & 1 & 1 & 1 & Wackstone \\
\hline 15 & BP-7a & 96 & - & 1 & 3 & - & Packstone \\
\hline 16 & BP-7b & 86 & 10 & 2 & 1 & 1 & Wackstone \\
\hline 17 & BP-8a & 90 & 6 & 2 & 1 & 1 & Packstone \\
\hline 18 & BP-8b & 97 & - & 1 & 1 & 1 & Packstone \\
\hline 19 & BP-8c & 96 & - & 1 & 2 & - & Packstone \\
\hline 20 & BP-9a & 95 & - & 2 & 2 & 1 & Wackstone \\
\hline 21 & BP-9b & 97 & - & - & 2 & 1 & Packstone \\
\hline 22 & BP-9c & 97 & - & - & 1 & 2 & Packstone \\
\hline Mean value & & 92 & 3.8 & 1 & 2 & 1.2 & \\
\hline 23 & BJ-10a & 96 & - & 1 & 2 & 1 & Packstone \\
\hline 24 & BJ-10b & 97 & - & 2 & 3 & - & Packstone \\
\hline 25 & BJ-10C & 96 & - & - & 2 & 2 & Wackstone \\
\hline 26 & BJ-11a & 97 & - & 1 & 1 & 1 & Wackstone \\
\hline 27 & BJ-11b & 96 & - & - & 2 & 2 & Wackstone \\
\hline 28 & BJ-11C & 97 & - & - & 2 & 1 & Wackstone \\
\hline 29 & BJ-12a & 98 & - & - & 2 & - & Packstone \\
\hline 30 & $B J-12 b$ & 95 & - & 2 & 3 & - & Packstone \\
\hline 31 & BJ-13a & 97 & - & - & 2 & 1 & Grainstone \\
\hline 32 & BJ-13b & 96 & - & 1 & 2 & 1 & Grainstone \\
\hline 33 & BJ-13C & 95 & - & 2 & 3 & - & Grainstone \\
\hline 34 & BJ-14a & 96 & - & - & 2 & 2 & Packstone \\
\hline 35 & BJ-14b & 97 & - & - & 2 & 1 & Packstone \\
\hline 36 & BJ-14C & 96 & - & 1 & 2 & 1 & Packstone \\
\hline Mean value & & 96.3 & 0 & 0.7 & 2.1 & 1 & \\
\hline
\end{tabular}

46]. Petrography of the carbonate rocks of the Bajar area reveals the occurrence of $95-97 \%$ calcite, $1-3 \%$ clays, $1-2 \%$ unstrained quartz and $1-2 \%$ hematite. Carbonate rocks without dolomite are considered non-reactive with respect to $A C R[13,21]$. The carbonate rocks of the Bajar area do not contain dolomite but $1-3 \%$ clays. These rocks contain 1-2\% unstrained quartz which does not initiate alkali-silica reaction (ASR) in concrete. So, these rocks are innocuous and can be used as an aggregate in cement concrete. However, the Bouhti Pind carbonate rocks contain $2-20 \%$ dolomite in addition to $75-97 \%$ calcite, $1-3 \%$ clays, $1-2 \%$ unstrained quartz and $1-2 \%$ hematite. Dolomite in association with clays is prone to alkali-carbonate reactivity (ACR) potential. Carbonate rocks possessing 40-90\% dolomite and 5-25\% clays cause deleterious expansion in concrete due to ACR [13, 19, 21, 46]. In Bouhti Pind, carbonate rocks dolomite and clays generally vary from 2 to $14 \%$ and 1 to $3 \%$, respectively. These deleterious minerals are lower than threshold values to cause ACR in cement concrete and are considered innocuous. Sample 
Table 3 Results of rock cylinder expansion test performed on the Bauhti Pind and Bajar carbonate rocks

\begin{tabular}{|c|c|c|c|c|c|c|c|c|c|c|}
\hline \multirow[t]{2}{*}{ S. no. } & \multirow[t]{2}{*}{ Sample no. } & \multicolumn{2}{|c|}{$\begin{array}{l}\text { Length of rock cylin- } \\
\text { ders } \mathrm{mm}\end{array}$} & \multicolumn{2}{|c|}{$\begin{array}{l}\text { Diameter of the rock } \\
\text { cylinders } \mathrm{mm}\end{array}$} & \multicolumn{2}{|c|}{$\begin{array}{l}\text { Volume of the rock } \\
\text { cylinders } \mathrm{mm}^{3}\end{array}$} & \multirow{2}{*}{$\begin{array}{l}\text { Expansion } \\
\text { after } 28 \text { days } \\
\%\end{array}$} & \multirow{2}{*}{$\begin{array}{l}\text { Deleterious } \\
\text { mineral constitu- } \\
\text { ents } \% \\
\text { Dolomite }\end{array}$} & \multirow[t]{2}{*}{ Clays } \\
\hline & & Initial & After 28 days & Initial & After 28 days & Initial & After 28 days & & & \\
\hline 1 & BP-1a & 35.25 & 35.25 & 09.25 & 09.25 & 2367.62 & 2367.62 & 0 & 10 & 2 \\
\hline 2 & BP-1b & 34.00 & 34.00 & 08.91 & 08.91 & 2118.86 & 2118.86 & 0 & 6 & 2 \\
\hline 3 & $\mathrm{BP}-2 \mathrm{a}$ & 35.62 & 35.62 & 10.33 & 10.33 & 2949.91 & 2949.91 & 0 & 6 & 1 \\
\hline 4 & $B P-2 b$ & 35.25 & 35.25 & 09.172 & 09.174 & 2327.86 & 2328.87 & 0.043 & 20 & 2 \\
\hline 5 & BP-2c & 36.00 & 36.00 & 09.83 & 09.83 & 2730.73 & 2730.73 & 0 & 10 & 2 \\
\hline 6 & BP-3 & 34.50 & 34.50 & 09.75 & 09.75 & 2537.21 & 2537.21 & 0 & 10 & 3 \\
\hline 7 & BP-4 & 35.75 & 35.75 & 09.41 & 09.41 & 2484.99 & 2484.99 & 0 & 0 & 2 \\
\hline 8 & BP-5 & 36.00 & 36.00 & 09.75 & 09.75 & 2686.46 & 2686.46 & 0 & 2 & 3 \\
\hline 9 & ВР-6а & 35.50 & 35.50 & 10.00 & 10.00 & 2786.75 & 2786.75 & 0 & 0 & 2 \\
\hline 10 & BP-6b & 36.00 & 36.00 & 09.08 & 09.08 & 2329.93 & 2329.93 & 0 & 0 & 3 \\
\hline 11 & BP-6c & 35.50 & 35.50 & 09.17 & 09.17 & 3240.79 & 3240.79 & 0 & 0 & 2 \\
\hline 12 & BP-7a & 35.00 & 35.00 & 09.83 & 9.83 & 2652.17 & 2652.17 & 0 & 0 & 3 \\
\hline 13 & BP-7b & 35.25 & 35.25 & 10.16 & 10.16 & 3109.14 & 3109.14 & 0 & 10 & 1 \\
\hline 14 & BP-8a & 35.75 & 35.75 & 09.41 & 09.41 & 2482.35 & 2482.35 & 0 & 6 & 2 \\
\hline 15 & BP-8b & 35.75 & 35.75 & 09.67 & 09.67 & 2621.49 & 2621.49 & 0 & 0 & 1 \\
\hline 16 & BJ-9a & 35.75 & 35.75 & 10.00 & 10.00 & 2806.37 & 2806.37 & 0 & 0 & 2 \\
\hline 17 & $B J-9 b$ & 35.75 & 35.75 & 09.41 & 09.41 & 2482.35 & 2482.35 & 0 & 0 & 1 \\
\hline 18 & BJ-9c & 35.37 & 35.37 & 08.75 & 08.75 & 2146.17 & 2146.17 & 0 & 0 & 1 \\
\hline 19 & BJ-10 & 35.25 & 35.25 & 09.41 & 09.41 & 2447.63 & 2447.63 & 0 & 0 & 2 \\
\hline 20 & BJ-11a & 35.00 & 35.00 & 09.33 & 09.33 & 2389.10 & 2389.10 & 0 & 0 & 2 \\
\hline 21 & $B J-11 b$ & 35.00 & 35.00 & 09.25 & 09.25 & 2348.28 & 2348.28 & 0 & 0 & 1 \\
\hline 22 & BJ-12a & 35.25 & 35.25 & 09.50 & 09.50 & 2497.3 & 2497.33 & 0 & 0 & 2 \\
\hline 23 & BJ-12b & 34.75 & 34.75 & 09.91 & 09.91 & 2676.29 & 2676.29 & 0 & 0 & 3 \\
\hline 24 & BJ-12C & 35.75 & 35.75 & 09.50 & 09.50 & 2532.75 & 2532.75 & 0 & 0 & 1 \\
\hline 25 & BJ-13a & 34.75 & 34.75 & 09.16 & 09.16 & 2288.84 & 2288.84 & 0 & 0 & 1 \\
\hline 26 & BJ-13b & 35.75 & 35.75 & 09.16 & 09.16 & 2354.70 & 2354.70 & 0 & 0 & 3 \\
\hline 27 & BJ-14a & 35.25 & 35.25 & 08.81 & 08.81 & 2145.29 & 2145.29 & 0 & 0 & 1 \\
\hline 28 & BJ-14b & 35.00 & 35.00 & 08.50 & 08.50 & 1985.06 & 1985.06 & 0 & 0 & 2 \\
\hline
\end{tabular}

BP- 2 b contains $20 \%$ dolomite along with $2 \%$ clays. Owing to lower dolomite and clays, the Bouhti Pind carbonate rocks are not prone to ACR.

The findings of petrographic analysis of the Bauhti Pind and Bajar area carbonate rocks were verified through rapid chemical method [5]. The test was performed to judge the expansion behaviour of the carbonate rock cylinders from both the area. The expansion of rock cylinder is directly linked with abundance of dolomite and clays in the rock. Owing to lack of dolomite and minor clay (1-3\%) content, the carbonate rock cylinders of Bajar area did not show any expansion. Likewise, the Bouhti Pind rocks did not reveal expansion behaviour due to lower mean dolomite (3.8\%) and clays (2\%) contents. However, rock cylinder BP- $2 \mathrm{~b}$ which contains $20 \%$ dolomite and $2 \%$ clays showed $0.043 \%$ expansion, lower than the specified limit of $0.10 \%$ of the ASTM (C-586) standard. The results shown in Table 3 are parallel with the observations of other researchers (e.g. $[13,19,21,33,46])$. The study suggests that dolomite and clay contents of Bouhti Pind carbonate rocks are lower than threshold values to initiate ACR in cement concrete. Hence, the carbonate rocks of Bouhti Pind and Bajar area are innocuous with respect to ACR and can be used as aggregate sources for the engineering projects.

\section{Conclusion}

Physical, chemical and petrographic analysis reveal suitability of carbonate rocks of the Bouhti Pind and Bajar areas as an aggregate in cement concrete and for the construction of roads. Specific gravity, water absorption, Los Angeles abrasion and sulphate soundness values of both the areas confirm their respective specified limits 
which indicate that these carbonate rocks may be used as a potential aggregate source. Petrographic study indicates the absence of dolomite in the rocks of Bajar area, while lower concentration of dolomite is found in Bouhti Pind rocks. Rock cylinder test does not show deleterious expansion in the carbonate rocks of both the areas which rule out the possibility of ACR. Hence, the carbonate rock aggregate of Bouhti Pind and Bajar areas is suitable for utilization as construction material.

\section{Compliance with ethical standards}

Conflict of interest On behalf of all authors, the corresponding author Tehseen Zafar states that there is no conflict of interest.

\section{References}

1. Ahsan N, Baloch IH, Chaudhry MN, Majeed CM (2000) Strength evaluation of blends of Lawrencepur, Chenab and Ravi sands with Lockhart and Margalla Hill Limestones for use in concrete. In: Economic Geology of Pakistan, Pakistan Museum of Natural History, Islamabad, pp 194-213

2. Alam GS, Jaleel A, Ahmad R (1992) Geology of the Kirana area, District Sargodha Punjab, Pakistan. Acta Mineral Pak 6:93-100

3. ASTM C-127-04 (2006) Standard test method for density, specific gravity and absorption of coarse aggregate. Annual book of ASTM standards, vol 04:02. ASTM International, West Conshohocken

4. ASTM C 131-03 (2006) Standard test method for resistance to degradation of small-size coarse aggregate by abrasion and impact in the Los Angeles machine. Annual book of ASTM standards, vol 04:02. ASTM International, West Conshohocken

5. ASTM C-586-05 (2006) Test method for potential alkali carbonate reactivity of carbonate rocks as concrete aggregate (rockcylinder method). Annual book of ASTM standards, vol 04:02. ASTM International, West Conshohocken

6. ASTM C-295-03 (2006) Guide for petrographic examination of aggregate for concrete. Annual book of ASTM standards, vol 04:02. ASTM International, West Conshohocken

7. ASTM C 88-05 (2006) Standard test method for soundness of aggregates by use of sodium sulfate or magnesium sulfate. Annual book of ASTM standards, vol 04:02. ASTM International, West Conshohocken

8. Calkins JA, Offield TW, Abdullah SKM, Ali ST (1975) Geology of the southern Himalaya in Hazara, Pakistan and adjacent areas. U.S. Geological Survey, Prof. Paper 716-C, p 29p

9. Chaudhry MN, Ahsan N, Zaka KJ, Majid M (1997) Alkali aggregate reaction potential of indus gravel and sand between Riakot Bridge and Kalabagh, Pakistan. In: National symposium on Economic Geology of Pakistan, April 2-3. Pakistan Museum of Natural History, Pakistan Science Foundation

10. Chaudhry MN, Baloch IH, Ahsan N, Majid CM (2000) Engineering properties, Mineralogy, Alkali Aggregate Reaction Potential and Provenence of Lawrencepur Sand Pakistan. Special Issue Pakistan Museum of Natural History, Pakistan Science Foundation, pp 241-254

11. de Cotter GP (1933) The geology of the part of the Attock Distt. Mem Geol Surv India 55:63-161
12. Dunham RJ (1962) Classification of carbonate rocks according to depositional texture. In: Ham WE (ed) Classification of carbonate rocks. American Association of Petroleum Geologists Memoir, pp 108-121

13. Farny JA, Kerkhoff B (2007) Diagnosis and control of alkaliaggregate reaction in concrete. Portland Cement Association, p 36

14. Fatmi AN (1973) Lithostratigraphic units of the Kohat-Potwar Province, Indus basin, Pakistan. Mem Geol Surv Pak 10:80

15. Gondal MMI, Javaid AZ, Chaudhry MN, Ahsan N (2007) An overview of geotechnical characteristics of coarse aggregates from Sargodha-Chiniot area, Margalla Pass and Sulaiman Range quarries in Punjab, Pakistan. National Geological Society of Pakistan, pp 1-20

16. Gondal MMI, Ahsan N, Javaid AZ (2009) Engineering properties of potential aggregate resources from eastern and central Salt Range, Pakistan. Geol Bull Punjab Univ 44:97-103

17. Harrison DJ (1992) Industrial minerals laboratory manual: limestone. British Geological Survey technical report WG/92/29

18. Hartley A (1974) A review of the geological factors influencing the mechanical properties of road surface aggregates. Q J Eng Geol 7(1):69-100

19. Hobbs DW (1988) Alkali silica reaction in concrete. Thomas Telford, London

20. Hylland MD (1990) Geology of southern Gandhar Range and Kherimar Hills, Northern Pakistan. Master of Science in Geology, Thesis. Oregon State University, p 15

21. Islam MS (2010) Performance of Nevada's aggregates in alkali aggregate reactivity of Portland cement concrete. University of Nevada Las Vegas, pp 88-91

22. Kazmi AH, Jan MQ (1997) Geology and tectonics of Pakistan. Graphic Publishers, Karachi, pp 1-554

23. Khan RA (2008) Role of construction sector in economic growth: empirical evidence from Pakistan economy. In: First international conference on construction in developing countries (ICCIDC-I) "Advancing and integrating construction education, research and practice" August 4-5, Karachi, Pakistan

24. Koukis G, Sabatakakis N, Spyropoulos A (2007) Resistance variation of low-quality aggregates. Bull Eng Geol Env 66:457-466

25. Langer WH (2004) Important features of sustainable aggregate resource management, vol 47. Vilniaus University, pp 99-108

26. Latif MA (1969) The stratigraphy of south eastern Hazara and parts of the Rawalpindi and Muzzaffarabad districts of West Pakistan and Kashmir [Ph.D. thesis].University of London, London, $\mathrm{p} 316$

27. Lees G, Kennedy CK (1975) Quality, shape and degradation of aggregates. Q J Eng Geol 8(3):193-209

28. Malkani MS, Mahmood Z (2016) Mineral resources of Pakistan: a review. Geol Surv Pak 128(i-iii):1-90

29. Malkani MS, Mahmood Z (2016) Revised stratigraphy of Pakistan. Geol Surv Pak 127(i-iii):1-87

30. Ngerebara OD, Youdeowei P (2014) Correlation of mechanical properties of some rocks in South Eastern Nigeria. Int J Sci Res Publ 4:1-6

31. Naeem M, Sadiq RA, Anwar M, Perveiz K (2014) Mechanical properties and petrographic characteristics of Margalla Hill limestone and Lockhart limestone of Rumli area, Islamabad Pakistan. Acta Geod Geophys 29(4):441-454

32. Powell CMA (1985) A speculative tectonic history of Pakistan and surroundings: some constrains from the Indian Ocean. In Farah A, DeJong KA (eds) Geodynamics of Pakistan Geological Survey of Pakistan, pp 5-24

33. Prentice JE (1990) Geology of construction materials. Chapman and Hall, London, p 202

34. Rahn PH (1986) Engineering geology, an environmental approach. Elsevier, Amesterdam 
35. Rehman A, Akram S, Zafar T (2017) Physical characterization of Wargal limestone, Barai Nala Section, Amb Sharif, Central Salt Range, Sub-Himalayas, Pakistan. In: International conference on mining and fuel industries (CMFI) October 19-21, Sheikh Zayed Islamic Research Center, Karachi, Pakistan. International Journal of Economic and Environment Geology

36. Ratschbacher L, Frisch W, Liu G, Chen CC (1994) Distributed deformation in southern and western Tibet during and after the India-Asia collision. J Geophys Res 99:17-45

37. Sadiq AB, Sameeni SJ, Ahmad SR, Mirza K, Karim AA (2014) Lockhart limestone of hazara area: a potential source for construction aggregate. Sci Int 26(5)

38. Sanaullah M, Khurshid HA, Zeeshan M, Zafar T, Zaman N (2017) Alkali carbonate reaction (ACR) susceptibility investigations for dolomite of early cambrian by physio-mineralogical techniques. In: International conference on mining and fuel industries (CMFI) October 19-21, Sheikh Zayed Islamic Research Center, Karachi, Pakistan. International Journal of Economic and Environment Geology

39. Searle MP, Parrish RR, Hodges KV, Hurford A, Ayres MW, Whitehouse MJ (1997) Shisha Pangma leucogranite, south Tibetan Himalaya: field relations, geochemistry, age, origin and emplacement. J Geol 105:295-317

40. Shah SMI (2009) Stratigraphy of Pakistan. Geological Survey of Pakistan (GSP), Ministry of Petroleum and Natural Resources, vol 22

41. Shakoor A, West TR, Scholer CF (1982) Physical characteristics of some Indiana argillaceous carbonates regarding their freezethaw resistance in concrete. Int Assoc Eng Geol 19(4):371-384

42. Siddiqi ZA, Hameed R, Saleem M, Khan QS, Ishaq I (2013) Performance study of locally available coarse aggregates of Azad Kashmir. Pak J Sci 65(1):90

43. Smith MR, Collis L (2001) Aggregates: sand, gravel and crushed rock aggregates for construction purposes. Special Publication, vol 17. Geological Society, London

44. Smith MR, Collis L (1993) Aggregates—sand, gravel and crushed rock aggregates for construction purposes, 3rd edn. The Geological Society London, London, p 339
45. Somro N, Malkani MS, Zafar T (2016) Evaluation of Kunhar River aggregate as a construction material, District Mansehra Khyber Pakhtunkhwa, Pakistan. In: International conference on: earth sciences Pakistan, 15-17 July. Journal of Himalayan Earth Sciences, $\mathrm{p} 151$

46. Swamy RN (1992) The alkali-silica reaction in concrete. Blackie, Glasgow, Scotland, and London, and Van Nostrand Reinhold, New York

47. Varghese PC (2015) Building material, 2nd edn. PHI Learning Pvt. Ltd, New Delhi

48. Yeats RS, Lawrence RD (1984) Tectonics of the Himalayan thrust belt in northern Pakistan. In: Haq BU, Milliman JD (eds) Marine geology and oceanography of Arabian Sea and coastal Pakistan. Van Nostrand Reinhold, New York, pp 177-198

49. Yeats RS, Hussain A (1987) Timing of structural events in the Himalayan foothills of northwestern Pakistan. Geol Soc Am Bull 99:161-176

50. Zaidi SM, Rafeeqi SFA, Ali MS, Khan AM (2008) Aggregate characterization - an important step towards addressing construction issues in Pakistan. In: First international conference on construction in developing countries (ICCIDC-I). Advancing and integrating construction education, research \& Practice, Karachi, Pakistan

51. Zafar T, Malkani MS, Zhendong T, Riaz M (2018) Aggregate prospects of Lockhart limestone of Watli and Sirali areas, eastern Salt Range, Pakistan. In; 5th international conference earth sciences Pakistan, Baragali Campus, Journal of Himalayan Earth Sciences, p 31

Publisher's Note Springer Nature remains neutral with regard to jurisdictional claims in published maps and institutional affiliations. 